\title{
COVID-19: a new emerging respiratory disease from the neurological perspective
}

\author{
Amr El-Sayed ${ }^{1} \cdot$ Lotfi Aleya $^{2} \cdot$ Mohamed Kamel $^{1}$ \\ Received: 1 September 2020 / Accepted: 10 February 2021 / Published online: 15 February 2021 \\ (C) The Author(s), under exclusive licence to Springer-Verlag GmbH, DE part of Springer Nature 2021
}

\begin{abstract}
Coronavirus disease 2019 (COVID-19) has become a challenging public health catastrophe worldwide. The newly emerged disease spread in almost all countries and infected 100 million persons worldwide. The infection is not limited to the respiratory system but involves various body systems and may lead to multiple organ failure. Tissue degenerative changes result from direct viral invasion, indirect consequences, or through an uncontrolled immune response. Severe acute respiratory syndrome coronavirus 2 (SARS-CoV-2) spreads to the brain via hematogenous and neural routes accompanied with dysfunction of the blood-brain barrier. The involvement of the central nervous system is now suspected to be among the main causes of death. The present review discusses the historical background of coronaviruses, their role in previous and ongoing pandemics, the way they escape the immune system, why they are able to spread despite all undertaken measures, in addition to the neurological manifestations, long-term consequences of the disease, and various routes of viral introduction to the CNS.
\end{abstract}

Keywords ACE2 receptors · COVID-19 - MERS $\cdot$ Neurological signs $\cdot$ SARS-CoV-2

\section{Introduction}

The sudden spread of the novel coronavirus worldwide released international panic and alarm signals. The novel SARS-CoV-2 virus responsible for the outbreak of respiratory illness was first observed in Wuhan, China, in December 2019. However, some reports refer to the earlier detection of the virus in clinical samples and sewage water in many western countries (Deslandes et al. 2020, Gemma Chavarria-Miró et al. 2020).

Many researchers discussed the reasons why coronavirus disease (COVID-19) spread, persisted, induced great economic losses, and represented a serious public health hazard, which include (1) the high contagiousness of the virus.

Amr El-Sayed and Mohamed Kamel contributed equally to this work

Responsible Editor: Philippe Garrigues

Mohamed Kamel

m_salah@staff.cu.edu.eg

1 Department of Medicine and Infectious Diseases, Faculty of Veterinary Medicine, Cairo University, Giza, Egypt

2 Chrono-Environnement Laboratory, UMR CNRS 6249, Bourgogne Franche-Comté University, F-25030 Besançon Cedex, France
Although the predominant mode of transmission is via respiratory droplets, some researchers reported that SARS-CoV-2 could behave as an airborne pathogen (Jayaweera et al. 2020; Zhang et al. 2020c; John et al. 2020). (2) Its ability to utilize various types of receptors to invade the tissues which expand its virus tissue tropism (Bittmann et al. 2020). (3) The continuous adaptation of the virus to the human host via mutations to develop more contagious and more virulent variants of the virus (Becerra-Flores and Cardozo 2020; Zhang et al. 2020b). (4) The persistence of the virus for a relatively long time inside the patients even after its clearance from the nasooral cavity (Ling et al. 2020; Wang et al. 2020). (5) Its excretion in various body fluids such as urine, milk, and nasal discharges (S. Costa et al. 2020, Fei Xiao et al. 2020, Holtmann et al. 2020, Colavita et al. 2020, Sun et al. 2020). (6) Its robustness to various environmental factors and sunlight. The virus is very robust and can persist in the environment for a relatively long time and keeps its infectivity during this period. Infected persons release viral bioaerosols that remain infectious for up to $16 \mathrm{~h}$ in site after viral shedding and airborne transport (Fears et al. 2020). The virus can also persist on animal skin, banknotes, cloths, frozen contaminated meat, and other surfaces for up to 4 weeks, depending on the surface and the surrounding temperature (Harbourt et al. 2020). (7) Exposure of the viral antigens to antigen- 
presenting cells (APCs) as macrophages activates the production of proinflammatory cytokines set, including IL-1, IL-4, IL-6, IL-8, MCSF, CXCL-10, and TNF- $\alpha$ (Alquisiras-Burgos et al. 2020; Gao et al. 2020) (Fig. 1). An unbalanced response to invasion may lead to what is known as storm of cytokine (Fig. 1), which is very serious and threatens the life of the patient ( $\mathrm{Li}$ et al. 2020a; Mahmudpour et al. 2020). (8) According to available data so far, the absence of the production of longstanding protective titer of antibodies was observed in many patients. The lifespan of the produced antibodies may not exceed 2-3 months according to the literature (Bachmann et al. 2021). This point is very serious as it hinders susceptible populations from achieving (herd immunity) status, prevents the development of an efficient protective vaccinal strategy, blocks the possibility of using plasma of recovered persons in the treatment of serious cases, and enables repeated infections of the same person (Long et al. 2020, Jiang et al. 2020, Marina Pollán et al. 2020, Lucas et al. 2020). (9) The presence of apparently healthy clinically normal shedders who harbor the virus without showing any clinical signs mostly children (Long et al. 2020; Bittmann et al. 2020). And finally, (10) its ability to escape the immune system and to develop a low titer of antibodies following infection (even no antibodies in some cases) which subjects the patients to be infected repeated times. This makes it difficult to develop a vaccine, the use of plasma in treatment and prevents the occurrence of herd immunity (Pollan et al. 2020, Marina Pollán et al. 2020).

\section{Classification and history of coronaviruses epidemics}

Coronaviruses, a Latin word for crown, were named after their characteristic crown-shaped under electron microscope. Coronaviruses (CoVs) are enveloped positive-sense RNA viruses. They are characterized by their club-like spikes (S) that project from their outer surface to facilitate adhesion to host receptors (Velavan and Meyer 2020) (Fig. 2). They own unusually large RNA genomes. Coronaviruses cause a variety of diseases in mammals and birds ranging from enteritis in cows and pigs and upper respiratory disease chickens to potentially lethal human respiratory infections. Coronaviruses (CoVs) are members of the Coronaviridae family. The family consists of two major subfamilies, Coronavirinae and Torovirinae. The corona members are divided in turn into four genera, Alpha-, Beta-, Gamma- and Deltacoronavirus. The viruses are characterized by enveloped positive-sense single-strand RNA particles. Their genomes are characterized by their large size (27$32 \mathrm{~kb}$ ) (Fehr and Perlman 2015). Both Alpha and Beta coronaviruses have restricted host affinity and can infect only mammals. Meanwhile, gamma and delta members target mainly birds with some exceptional members that can infect mammals also (Woo et al. 2012).

Betacoronavirus, can be divided into five subgenera (Nobecovirus, Hibecovirus Embecovirus, Sarbecovirus, and Merbecovirus) with a clear zoonotic potential for the last two subgenera (such as SARS-CoV1, MERS, and SARSCoV-2 viruses as will be discussed later) (Wong et al. 2019; Cui et al. 2019; Dong et al. 2020). The first defined

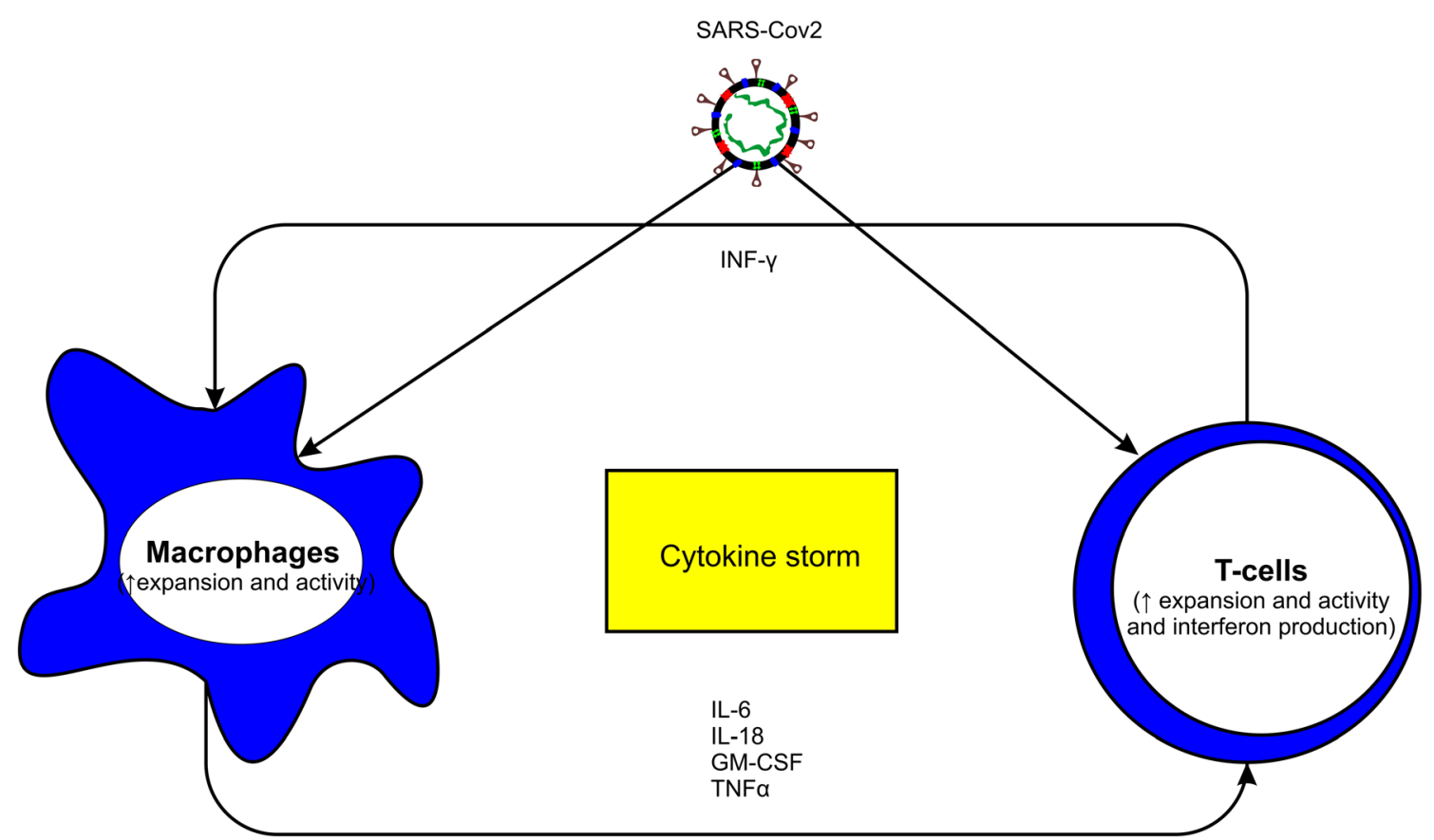

Fig. 1 Cytokine storm induced by SARS-CoV-2 


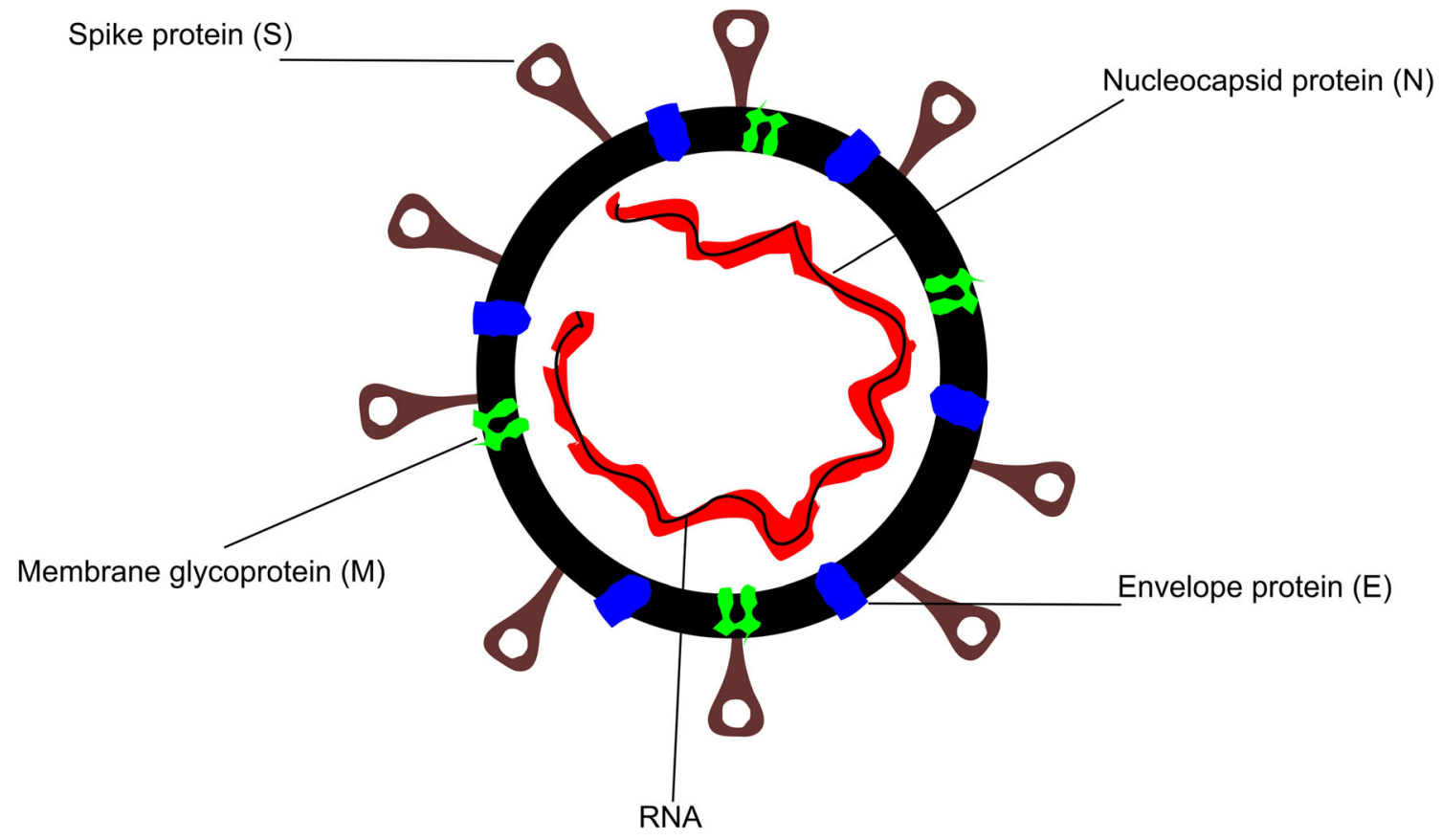

Fig. 2 Schematic diagram of SARS-CoV-2

coronavirus was the avian infectious bronchitis virus, which was isolated in 1937. This was followed by discovering another two animal pathogens in the 1940s, namely, the mouse hepatitis virus and the porcine transmissible gastroenteritis virus (Alluwaimi et al. 2020). Later on, in the 1960s, the first human coronavirus could be identified together with the porcine hemagglutinating encephalomyelitis virus. Several coronaviruses could be reported in the following decade, such as the turkey coronavirus, the bovine coronavirus, the porcine epidemic diarrhea virus, the feline coronavirus, and the canine coronavirus. In the $1980 \mathrm{~s}$, the swine pathogen (porcine respiratory coronavirus) was identified as the last corona member to be reported in the 20th century (SAIF 2004; Leyi 2016). With the beginning of the 21 st century, coronaviruses started to induce serious human epidemics (severe acute respiratory syndrome (SARS-CoV1 and SARS-CoV-2)) in 2002 and 2019, respectively, in addition to MERS-CoV (Middle East Respiratory Syndrome) virus in 2012:

\section{SARS-CoV-2 structure}

Like other coronaviruses, the SARS-CoV-2 genome consists of 10-12 ORFs that encode both structural and nonstructural proteins. While the nonstructural proteins are needed for virus processing and replication, the structural proteins (spike (S), envelope (E), membrane (M), and nucleocapsid (N) proteins) are essential for assembly and release of the new viral particles from the infected host cells (Pooladanda et al. 2020). The structural proteins play different roles: while the $(\mathrm{M})$ protein is responsible for virus assembling and shaping, the (E) protein is required for the budding and envelop assembling; the $(\mathrm{N})$ protein interacts with the viral RNA to form the helical ribonucleocapsid complex. Indeed, the spike protein (S) attracted more attention as it is responsible for viral binding to ACE2 receptors and entry to the host cells (Gheblawi et al. 2020). Moreover, the (S) proteins play a major role in SARSCoV-2 invasion of human fetal brain during pregnancy (Varma et al. 2021) and are responsible for the olfactory, taste, and chemesthesis disorders characteristic to COVID-19 (Maaroufi 2021). In addition, they have a significant role in the induction of proinflammatory response in the brain endothelial cells which has a negative impact on the functionality of the blood-brain barrier (BBB), facilitating the passage of the virus through the $\mathrm{BBB}$ as reported recently (Buzhdygan et al. 2020; Rhea et al. 2020). The (S) proteins are surfaceanchored glycoproteins. Therefore, they are the main target of the host neutralizing antibodies. Beside the (S) protein, antiSARS-CoV-2 antibodies are also directed to attack the $(\mathrm{N})$ protein and other epitope proteins as ORF 8 to a less extent (Schwarzkopf et al. 2021). Fortunately, the structure of (S) protein and the way it interacts with the hot receptors are now understood which supports the running vaccine and antiviral development efforts (Papageorgiou and Mohsin 2020a)

It is now clear that the $(\mathrm{S})$ protein consists of two subunits called (head/S1) and (stalk/S2) subunits. While the head part is responsible for binding to ACE2 receptor, the stalk portion is essential for membrane fusion (Jaimes et al. 2020). Receptor binding was shown to take place through the interaction between the receptor binding domain (RBD) present in the $\mathrm{S} 1$ subunit and the peptidase domain (PD) of the host ACE2 receptors. The RBD protein is the most flexible 
segment of SARS-CoV-2 and has a very high affinity to human ACE2 receptors (Hussain et al. 2020). However, to complete the infection process, cleavage of S2 subunit by the host Transmembrane Protease Serine 2 (TMPRSS2) is required as the S2 cleavage enhances the integration of HR1 and HR2 domains of S2 subunit to form a six-helix bundle structure fusion core, which enables the fusion of the virus with the cell membrane (Papageorgiou and Mohsin 2020b; Xia et al. 2020).

As the (S) protein presents on the virus's surface, it is directly exposed to the immune system. Therefore, in order to escape neutralization by the immune system, (S) protein glycosylation is carried out. The glycosylation process aims to protect receptor binding epitopes from being discovered and neutralized by the antibodies (Watanabe et al. 2020). An additional mechanism to escape the immune system includes the evolution of new mutations. In the last few months, several mutations of SARS-CoV-2 were reported in the UK, South Africa and Brazil (Mahase 2021). Mutations increase the risk of evolving more virulent and contagious strains and increase the risk of escaping virus neutralization by pre-existing antibodies produced due to previous exposure or vaccination. This, in turn, represents an obstacle to the development of antiviral preparations and vaccine design (Hie et al. 2021).

\section{Receptors of the virus}

The receptors are present in different tissues; however, the severity of the disease varies among people. While some may get the infection asymptomatically, the disease can end fatally in others. This difference in disease susceptibility is attributed to age, sex, general health condition/ disease status, blood group, race, lifestyle (e.g., smoking), and genetic factors (influencing the immune response, variations in ACE receptors and even blood group) [Hussain et al. 2020; Smith et al., 2020; Scully et al., 2020; Davies et al., 2020; Bahlo, 2020 (Das et al. 2020)]. Following the introduction of the virus to the human body, the invading viral particles adhere to the cell receptors by their spike (S) protein (Fig. 3). The distribution and availability of target receptors determine both viral tissue tropism and host range. In the human body, $\mathrm{CoV}$ can use one or more of the following receptor: (1) ACE2 (angiotensinconverting enzyme 2/e.g., SARS-CoV 1 and 2) and HCoVNL63 (2) DPP4 (dipeptidyl peptidase 4)/e.g., MERS-CoV. (3) aminopeptidase $\mathrm{N}$ by $\mathrm{HCoV}-229 \mathrm{E}$ and (4) 9-O-acetylated sialic acid by $\mathrm{HCoV}-\mathrm{OC} 43$ and -HKU1 viruses. As a result, viruses that target ACE2 receptors, mainly infect type II pneumocytes and ciliated bronchial epithelial cells. Meanwhile, those target DPP4 receptors infect mainly unciliated bronchial epithelial cells based on receptor availability (Cui et al. 2019; Li et al. 2003; Yeager et al. 1992; Li et al. 2007; Wu et al. 2009; van Doremalen et al. 2014; Jeffers et al.
2004). According to newly published data, SARS-CoV-2 may utilize alternative receptors rather than the ACE2, namely, TMPRSS2, Cathepsin-L/B (CTSB and CTSL), CD-147 Receptor (Bittmann et al. 2020; Goad et al. 2020).

In addition to the cellular heparan sulfate, which forms a complex of heparan sulfate and ACE2 to facilitate viral entrance (Clausen et al. 2020), the presence of SARS-CoV-2 receptors in different tissues enables the virus from invading various organs in the body including lungs, heart, blood vessels, eyes, digestive tract, the endocrine and male reproductive systems and the central nervous system (Fig. 3) (Li et al. 2020c).

It is also proposed that the respiratory signs accompanying COVID-19 have multifactorial initiators with the direct involvement of the nervous system. For example, it has been proposed that pulmonary oedema is partially induced by the nervous system. According to this hypothesis, the SARSCoV-2 induces inflammatory reactions in the nucleus tractus solitarius (NTS) via the axon of VII, IX, and X cranial nerves, which trigger pulmonary oedema (Anoop and Verma 2020).

Respiratory failure, the major lethal manifestation of COVID-19, could be neurogenic in origin according to some reports which linked the respiratory failure and the occurrence of Ondine curse syndrome to dorsolateral medullary stroke (Fiedler and Gill 2020; Li et al. 2020d).

Others attributed the induction of the respiratory failure to the direct viral neuroinvasive potential to invade the cardiorespiratory regulation center in the brain stem. However, this point requires more investigation ( $\mathrm{Li}$ et al. 2020d; Román et al. 2020; Scoppettuolo et al. 2020; Das et al. 2020; Chigr et al. 2020).

The involvement of the entire nervous system was reported in about $25-36.4 \%$ of the patients who develop variable levels of neurological symptoms. Out of these, about $84 \%$ develop neurological complications. The commonly described complaints and their prevalence included [17\% (dizziness), 13\% (headache), and 7\% (impaired consciousness)], cerebrovascular events $(62 \%)$ [ischemic strokes $(46 \%)$, intracerebral hemorrhages (7\%), CNS vasculitis (1\%), and other cerebrovascular events $(8 \%)$, alteration of the mental status (31\%) [encephalopathy (13\%) \& encephalitis $(6 \%)]$, and finally various neuropsychiatric signs (18\%) [psychosis ( $8 \%)$, neurocognitive (dementia-like) syndrome $(5 \%) \&$ affective disorders (3\%)] (Ellul et al. 2020; Li et al. 2020b; Struyf et al. 2020). The present review will focus on the pathophysiological \& pathopsychological effects of the SARS-CoV-2 virus on the central nervous system will be discussed in detail.

\section{COVID-19 and the nervous system}

Recent studies describe SARS-CoV-2 as a neuroinvasive, neurotropic, and neurovirulent virus (Lima et al. 2020). 
Fig. 3 Binding and internalization of SARS-CoV-2 via ACE2 receptors and destruction of ACE2-producing tissues

SARS-Cov2

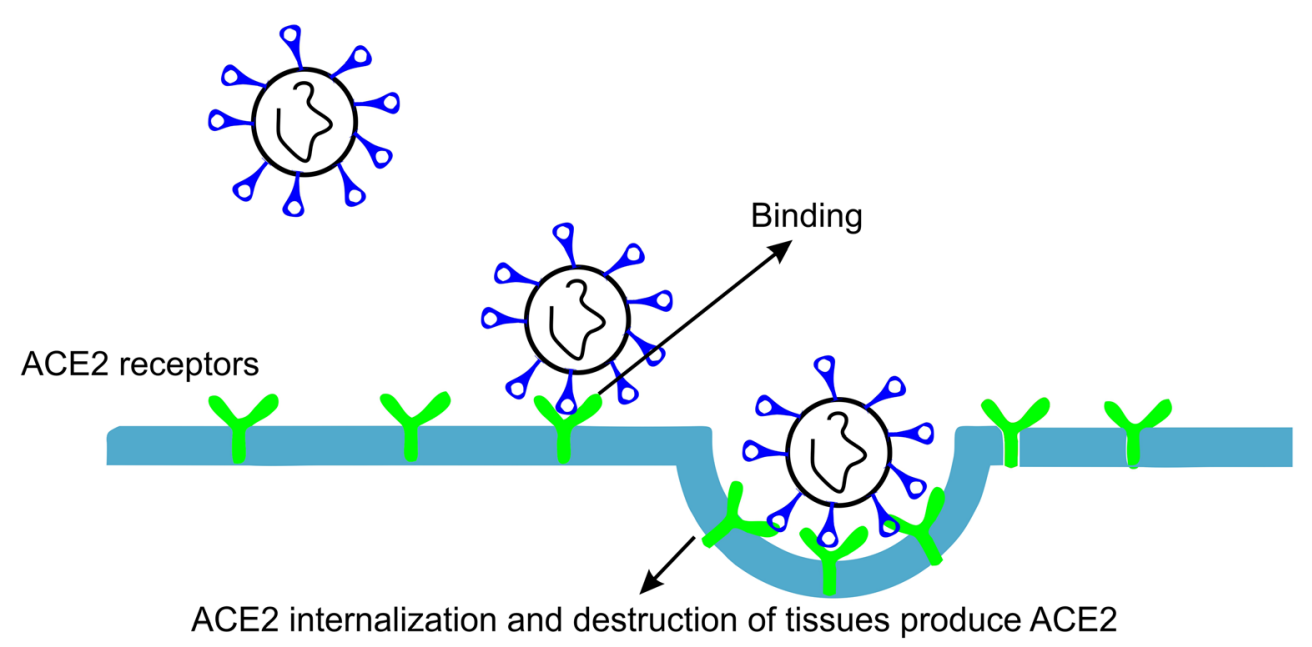

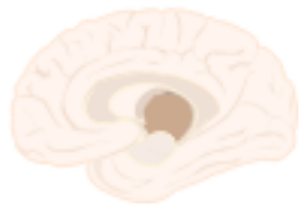

Brain

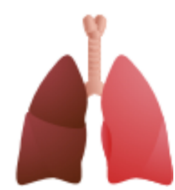

lung

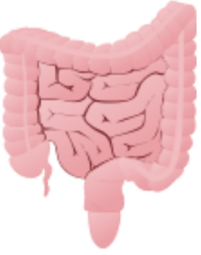

Enterocytes

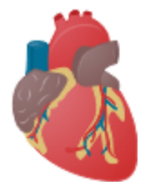

Heart

and many other organs and cells as endothelial cells, ....

Following the entry of the virus, it remains in the oro-nasal cavity for a short time before binding to cells expressing ACE2 receptors such as the olfactory epithelial support cells, stem cells, in addition to the nasal respiratory epithelium, that can express both ACE2 and TMPRSS2 receptors. The virus enters the cells by fusion with the cell membrane. Although SARS-CoV-2 stands for severe acute respiratory syndrome, the virus affects various body organs and systems with a variable degree of severity. Among the greatly affected systems in the body is the nervous system leading to the emergence of neurological and neuropsychiatric signs (Alquisiras-Burgos et al. 2020). The first signs of COVID-19 infection include fever, myalgia or arthralgia, fatigue, and headache, which are the COVID-19 infection alarm/red flags (Li et al. 2020b, Struyf et al. 2020). The neurological symptoms develop in about one-third of the patients due to direct and indirect involvement of the nervous system during the course of the disease. Unfortunately, the used ACE2 receptors represent a cardio-cerebral vascular protection element which play a major role in regulating blood pressure and exert an antiatherosclerosis mechanism. SARS-CoV-2 binding to the receptors results in the elevation of the blood pressure and increases the risk of a cerebral hemorrhage. Meanwhile, antibodies against the virus antigens can attack human selfantigens in the cerebral vascular endothelial cells leading to the BBB disruption (Scoppettuolo et al. 2020). Moreover, SARS-CoV2 can affect the integrity of the BBB by various mechanisms, trigger severe and prolonged neuroinflammatory reactions, capable of invading the brain tissue via different routes and exerts cytotoxic effects resulting in degenerative changes in infected tissues (Alquisiras-Burgos et al. 2020). The damage of the BBB may also result from the direct interaction between the S protein and the ACE2 receptors, which are highly expressed in the CNS vessels and capillary endothelium, according to some reports. The resulting damage of the BBB enables the passage of the virus to the brain ( $\mathrm{Wu}$ et al. 2020; Scoppettuolo et al. 2020).

According to the available data, the involvement of the central nervous system can be achieved via a dual pathway (Fig. 4), directly via the transsynaptic route (olfactory bulb, the only part of the CNS not protected by dura), indirectly through hematogenous dissemination (Huang et al. 2020; Chigr et al. 2020; Das et al. 2020), through neuronal retrograde dissemination or the trans-cribrial route (Baig and Sanders 2020), through the trigeminal nerve, peripheral nerves, the CSF or via the nerve ending in gastro-intestinal tract (gut-brain axis). All these routes were proposed based on current evidences (Satarker and Nampoothiri 2020; Tremblay et al. 2020; Lima et al. 2020; Jakhmola et al. 2020). The second pathway is the hematogenous dissemination; this, in 


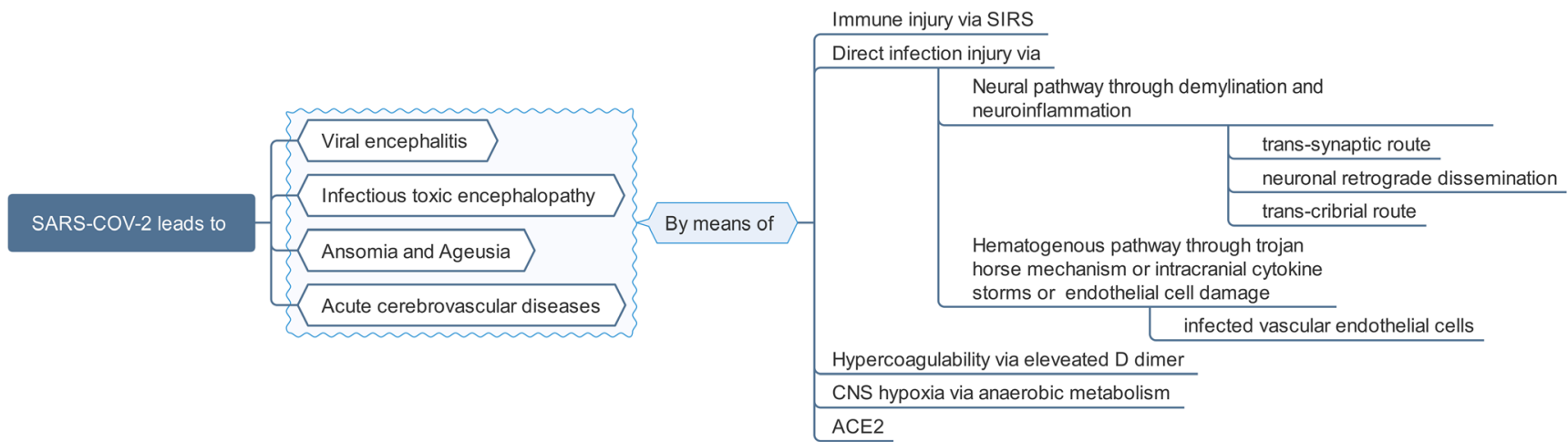

Fig. 4 Postulated mechanisms of effect of SARS-CoV-2 on nervous system

turn, takes place via different possibilities: (1) Transported to CNS through infected vascular endothelial cells, which normally express ACE2 receptors. The virus could be detected in brain samples from the capillary endothelial and neurons of a frontal lobe specimen (Paniz-Mondolfi et al. 2020). (2) Using the Trojan horse mechanism (i.e., introduction of the virus to the CNS with infected WBCs which pass through the BBB) which is also used by several other viruses (Park 2020; Jakhmola et al. 2020; Kamel et al. 2020; Desforges et al. 2019). And finally, (3) hematogenous route through the compromised $\mathrm{BBB}$ as a result of intracranial cytokine storms (Zubair et al. 2020; Poyiadji et al. 2020; Garg 2020). These findings were confirmed by the direct detection of viral particles in the CSF of many patients (Ellul et al. 2020). Unfortunately, once the virus enters the CNS, viral clearance is not possible as the immune response in the CNS is limited to cytotoxic T lymphocytes alone due to the lack of major histocompatibility antigens in the CNS. The infection of the brain tissues and the resulting inflammation could be responsible for the occurrence of most of the nervous signs (Sheraton et al. 2020). On the other hand, although the glial cells (e.g., astrocytes and microglia) are principally involved in the neuroinflammatory process of the brain, their role becomes restricted upon infections by neurotropic viruses. Recent reports discussing the neurotropism of SARS-CoV-2 suggested implications of glial cells as targets of SARS-CoV-2 leading to glial cell dysfunctions (Vargas et al. 2020). Moreover, the migration of SARS-CoV-2 infected microglia across healthy brain regions may spread and exaggerate the neuroinflammation process (Tremblay et al. 2020).

As mentioned before, SARS-CoV-2 is a multitropic virus. The virus has an affinity to various body systems such as the respiratory system, digestive system, endothelial cells, and nervous system. The neurological signs accompanying infection with SARS-CoV-2 may result from direct viral infection to the nervous system or develop in response to multiple organ failure, hypoxia, inflammation or sepsis. The increase in inflammatory mediators and C-reactive protein (CRP) levels accompanied with lymphopenia were reported. In addition, in some patients, cytokine storm syndrome characterized by secondary hemophagocytic lymphohistiocytosis may occur, requiring regular monitoring of ferritin level during the course of the disease (Mehta et al. 2020). Therefore, to reduce the risk of acute cerebrovascular complications, early targeting of antiinflammatory pathways is recommended (Jha et al. 2021). The combined use of corticosteroids, anti-IL-6 antibody (tocilizumab), or anti-IL-1 therapy (anakinra) was successfully applied to reduce the mortality rate (Narain et al. 2020).

The appearance of nervous signs may even precede the occurrence of fever and respiratory manifestations. Symptoms like the loss of smell and taste may even represent the only clinical signs in some patients (Hjelmesæth and Skaare 2020; Carrillo-Larco and Altez-Fernandez 2020). In general, the reported neurological symptoms can be divided into three different categories: symptoms related to the involvement of the central nervous system, such as (headache, ataxia, dizziness, epilepsy, impaired consciousness, and acute cerebrovascular disease), symptoms attributed to the involvement of the peripheral nervous system (including loss of taste, loss of smell, hypoplasia, and neuralgia), and finally musculoskeletal symptoms (Mao et al. 2020b).

The involvement of nervous system results in serious damages which may persist even after the complete recovery of other body systems, the damages include encephalopathy (in absence of direct CNS invasion), and encephalitis (induced by a direct viral invasion of the CNS) (Fig. 4). The nervous manifestations begin usually with headache, the loss or perturbation of taste (dysgeusia or ageusia) and loss of smell (anosmia or hyposmia) in most cases. The impairment of smell and taste was noticed in $81 \%$ and $94 \%$, respectively. Additional signs like dizziness, impaired consciousness (ranging from mild confusion, delirium, up to deep coma) ischemic stroke occurred in $(17 \%, 13 \%, 7.5 \%$ and $0.9 \%)$, respectively. Meanwhile, visual disturbances and neuralgia were noticed in $2.3 \%$ and $1.4 \%$, respectively. Other manifestations as paresthesia, hallucinations, and seizures were reported with a lower prevalence (Yaghi et al. 2020; Sheraton et al. 2020; Passali and Bentivoglio 2020; Lechien et al. 2020). In another meta-analysis, the most common neurologic sign was the myalgia $(19.2 \%)$, followed by headache $(10.9 \%)$, dizziness 
(8.7\%), and underlying cerebrovascular disease $(8.5 \%)$ and followed to less extent by nausea, concurrent cerebrovascular disease, and impaired consciousness in $3.8 \%, 4.6 \%$, and $4.4 \%$, respectively (Pinzon et al. 2020a). Other signs were noticed on patients during their ICU stay such as confusion, agitation, signs of upper motor neuron syndrome as hyperreflexia with clonus and positive Babinski's sign, and dysexecutive syndrome. These signs were reported in $65 \%$, $69 \%, 69 \%$, and $33 \%$ of the studied cases, respectively (Sheraton et al. 2020).

As previously mentioned, the virus exerts its effect on both central and peripheral nervous systems via multiple pathological pathways, including formation of microthrombi, induction of acute infarctions due to hypoxic-ischemic reactions, ischemic strokes, and local inflammation of the brain tissue accompanied with parenchymal infiltrates of T-lymphocytes (Koralnik and Tyler 2020b; Kantonen et al. 2020; Koralnik and Tyler 2020a). Other serious nervous signs which are less frequent but could be life-threatening are encephalopathy, acute necrotizing hemorrhagic encephalopathy, meningoencephalitis, posterior reversible encephalopathy syndrome, or nerve root enhancement, post-COVID-19 CNS demyelination, brainstem, and cortical autoimmune encephalitis and Guillain Barré Syndrome (GBS). The prevalence of the acute cerebrovascular diseases was higher in elderly patients and those suffering from chronic diseases as type 2 diabetes (Poyiadji et al. 2020; Koralnik and Tyler 2020a; Paterson et al. 2020b; Mao et al. 2020a).

In addition to the harmful effects resulting from the direct viral invasion of the neurons, additional damage may occur due to the undesired adaptative immune response in which anti-SARS-CoV-2 antibodies produced by the immune system exert cross-reaction with the PNS and the brain microvascular endothelial cells to induce BBB dysfunction, neuronal dysfunction (such as acute motor axonal neuropathy (AMAN), Miller-Fisher-variant, and GBS). The most common neurological signs are summarized in Table 1 (GutiérrezOrtiz et al. 2020; Sedaghat and Karimi 2020; Ellul et al. 2020; Alquisiras-Burgos et al. 2020).

Understanding the disease pathogenesis provides an explanation for COVID 19 associated neurological signs. Animal experiments showed that the loss of smell and taste is believed to be a result of direct nerve invasion by the virus (Netland et al. 2008; Meppiel et al. 2020; Scheidl et al. 2020b). According to the majority of the reports, the most common nervous sign of COVID-19 is the severe headache (Rodriguez-Morales et al. 2020; Pleasure et al. 2020). Headache is also a common sign of encephalitis, meningitis, intracranial hypertension, and vasculitis. However, the characteristic severe headache accompanying COVID-19 infections is attributed most probably to metabolic acidosis. Lung affection results in generalized oxygen deficiency, which, in turn, results in a state of CNS hypoxia. The hypoxia results, in addition, from the direct viral invasion of the cardiorespiratory centers in the medulla (Netland et al. 2008, Meppiel et al. 2020, Scheidl et al. 2020b). The performance of anaerobic metabolism due to oxygen deficiency leads to the accumulation of lactic acid in the tissues (Chhetri et al. 2020). The metabolic acidosis induces cerebral vasodilation and interstitial edema in addition to a swelling of brain cells, and finally, obstruction of cerebral blood flow occurs. The congestion and ischemia are the main inducers of severe pain and headache (Mao et al. 2020a; Pinzon et al. 2020b). Additional causes for the headache were also reported where the headache was linked to the neurotropic affinity of the virus, following invading the brain and activating the glial cells, a severe proinflammatory state will be invoked. The severe inflammation results similarly in edema and swelling of the brain tissues, which, in turn, strengthens the headache. (Pinzon et al. 2020a).

The occurrence of cerebrovascular disease is attributed to the induced coagulopathy due to the damage of the endothelial cells by the virus, which leads to the activation of the inflammatory and thrombotic pathways (Zhang et al. 2020a). On the other hand, the induction of acute ischemic stroke may be triggered by the early inflammatory process, which follows acute infection. This, in turn, results in destabilizing the carotid plaques or generating atrial fibrillation (Ellul et al. 2020). While the occurrence of anosmia (loss of smell) and the olfactory dysfunction as one of the earliest signs of the diseases can now be explained. This is attributed to the elevated ACE2 expression in the olfactory neuroepithelium. Higher receptor expression in upper respiratory epithelium than in lower respiratory and alveolar epithelium confirms the previously published data referring to the upper respiratory epithelium as the main site of SARS-CoV-2 entry to the body. The virus particle copy number could be detected in nasal swabs $(\sim 200$ fold) of that in pharyngeal swabs or bronchoalveolar lavage (Chen et al. 2020a, b). Meanwhile, the impairment of consciousness, seizures, encephalopathy and meningitis are all consequences of the direct adhesion of the SARS-CoV-2 to the ACE2 receptors in the brain tissues (Moriguchi et al. 2020; Poyiadji et al. 2020).

In addition to the previously listed nervous signs, several psychiatric and neuropsychiatric disorders were also reported in association with COVIS-19, including confusion, depression, anxiety, impaired memory, and insomnia at variable levels. In addition, steroid-induced mania and psychosis irritability, and fatigue were also reported (Rogers et al. 2020). Many of these psychotic symptoms can persist for a long time such as the aggressive behaviour, auditory hallucinations, Capgras delusion, persecutory delusions, and complex systematized delusional misperceptions (Poyiadji et al. 2020; Koralnik and Tyler 2020a; Paterson et al. 2020a). The explanation of the occurrence of neuropsychiatric signs is the combined effect of hypoxia and the induced neuroinflammation, 
Table 1 List of the most commonly reported neurological symptoms in association with COVID-19 epidemic. The major COVID-19 neurological abnormalities which were reported in medical publications

\begin{tabular}{|c|c|c|c|}
\hline SARS-CoV-2 induces & Resulting in: & As a consequence/manifested by: & Reference \\
\hline \multirow[t]{4}{*}{ Systemic infection } & $\begin{array}{l}\text { Multiple organ } \\
\text { failure }\end{array}$ & $\begin{array}{l}\text { Headache } \\
\text { Encephalitis and encephalopathy (hypoxic and metabolic forms) accompanied } \\
\text { by CNS dysfunction } \\
\text { Altered sensorium (agitation, delirium, and coma) }\end{array}$ & (Garg et al. 2020) \\
\hline & $\begin{array}{l}\text { Coagulopathy and } \\
\text { acute } \\
\text { cerebrovascular } \\
\text { disease }\end{array}$ & $\begin{array}{l}\text { Ischemic and hemorrhagic cerebrovascular accident (CVA) } \\
\text { Large-vessel Ischemic stroke } \\
\text { Multiple infarcts, cerebral venous thrombosis } \\
\text { Intracerebral hemorrhage and subarachnoid hemorrhage } \\
\text { Multiple vascular territories manifested by focal motor and sensory disorders, } \\
\text { acute intracranial vasculopathy } \\
\text { Multiinfarct dementia }\end{array}$ & $\begin{array}{l}\text { (Zhang et al. 2020d, } \\
\text { Sharifi-Razavi et al. } \\
\text { 2020, Coolen et al. } \\
\text { 2020, Román et al. } \\
\text { 2020) }\end{array}$ \\
\hline & $\begin{array}{l}\text { Severe } \\
\text { inflammatory } \\
\text { reactions (storm } \\
\text { of cytokines) }\end{array}$ & $\begin{array}{l}\text { Kawasaki like (in children), antiphospholipid antibodies, SIRS-like syndrome } \\
\quad \text { (systemic inflammatory response syndrome) } \\
\text { Inflammatory encephalopathy and encephalitis } \\
\text { Infectious toxic encephalopathy and encephalitis accompanied with altered } \\
\quad \text { mental status } \\
\text { Seizures } \\
\text { Dysexecutive syndrome } \\
\text { Meningitis }\end{array}$ & $\begin{array}{l}\text { (Zhang et al. 2020e, } \\
\text { Mehta et al. 2020, } \\
\text { Wu et al. 2020, Jha } \\
\text { et al. 2021) }\end{array}$ \\
\hline & $\begin{array}{l}\text { Targeting ACE2 } \\
\text { receptors }\end{array}$ & Cerebral hemorrhage, damage of BBB & (Wu et al. 2020) \\
\hline $\begin{array}{l}\text { Abnormalities due to } \\
\text { invasion of the PNS }\end{array}$ & $\begin{array}{l}\text { Neuros infection } \\
\text { and dysfunction } \\
\text { (branches of } \\
\text { facial nerve) } \\
\text { and/or other } \\
\text { cranial nerves } \\
\text { (e.g., optic } \\
\text { nerve). } \\
\text { Neuropathy and } \\
\text { muscular injury } \\
\text { (myalgia) }\end{array}$ & $\begin{array}{l}\text { Dysgeusia and ageusia/anosmia and hyposmia } \\
\text { Acute myelitis } \\
\text { Visual disturbances } \\
\text { Neuralgia } \\
\text { Polyneuritis cranialis } \\
\text { Direct affection of muscles (atonia and paresis) } \\
\text { Amblyopia (lazy eye syndrome), } \\
\text { acute flaccid myelitis in some cases } \\
\text { Facial muscle weakness may affect the functionality of the eyelids and lacrimal } \\
\text { system } \\
\text { Manifested by loss of smell, taste and muscular weakness/pain. } \\
\text { The infection may extend to the cardiorespiratory center. }\end{array}$ & $\begin{array}{l}\text { (Oxley et al. 2020, } \\
\text { Eliezer et al. 2020, } \\
\text { Wei et al. 2020, } \\
\text { Edwards et al. 2020, } \\
\text { Koralnik and Tyler } \\
\text { 2020a, } \\
\text { Carrillo-Larco and } \\
\text { Altez-Fernandez } \\
\text { 2020) }\end{array}$ \\
\hline $\begin{array}{l}\text { Abnormalities due to } \\
\text { invasion of the CNS } \\
\text { (mostly } \\
\text { inflammation-- } \\
\text { mediated) }\end{array}$ & $\begin{array}{l}\text { Corticospinal tract } \\
\text { dysfunction }\end{array}$ & $\begin{array}{l}\text { Meningoencephalitis, } \\
\text { Subarachnoid invasion responsible for the characteristic headache and nuchal } \\
\text { rigidity, } \\
\text { Endothelialitis } \\
\text { The signs occur due to the direct viral invasion and the resulting inflammation } \\
\text { Central hypopnea respiratory failure due to the involvement of brain stem. } \\
\text { Alteration of mental status (AMS) } \\
\text { ataxia }\end{array}$ & $\begin{array}{l}\text { (Bernard-Valnet et al. } \\
\text { 2020, Li et al. 2020d, } \\
\text { Román et al. 2020) }\end{array}$ \\
\hline $\begin{array}{l}\text { Abnormalities due to } \\
\text { post-infection }\end{array}$ & $\begin{array}{l}\text { Immune-mediated } \\
\text { reactions }\end{array}$ & $\begin{array}{l}\text { Acute disseminated encephalomyelitis, (ADEM) manifested by headache. } \\
\text { Acute necrotizing encephalopathy (ANE). } \\
\text { Immune-mediated inflammatory encephalitis. } \\
\text { Guillain Barré syndrome (GBS also known as acute inflammatory } \\
\text { demyelinating polyneuropathy (AIDP)) manifested by muscular flaccidity, } \\
\text { myopathy, and multilimb weakness } \\
\text { Acute hemorrhagic necrotizing encephalopathy (AHNE) } \\
\text { CNS-demyelinating lesions } \\
\text { Miller-Fisher syndrome (MFS) }\end{array}$ & $\begin{array}{l}\text { (Dixon et al. 2020, } \\
\text { McArthur 2020, } \\
\text { Pleasure et al. 2020, } \\
\text { Zanin et al. 2020, } \\
\text { Gutiérrez-Ortiz et al. } \\
\text { 2020, Li et al. 2020b, } \\
\text { Román et al. 2020, } \\
\text { Ellul et al. 2020, Jha } \\
\text { et al. 2021) }\end{array}$ \\
\hline
\end{tabular}

which damages the hippocampal and cortical areas resulting in neuropsychiatric signs (Steardo et al. 2020).

Little data are available through brain changes in autopsies of deceased cases suffered from COVID-19. Such data is important to clarify the neuroinfection track of COVID-19 in order to establish appropriate measures (Das et al. 2020).
The reported autopsy findings included edema of the brain tissue (Xu et al. 2020). Cerebral and dotted subarachnoid hemorrhages, signs of ischemic necrosis, encephalopathy, broad gliocyte hyperplasia and diffuse vascular congestion (Chen et al. 2020b; Ellul et al. 2020; Huang et al. 2020; VasquezBonilla et al. 2020). In addition, generalized hypoxic changes 
in the cerebellum and cerebrum accompanied by neuronal loss in the hippocampus, cerebral cortex, and in the cerebellar Purkinje cell layer were also reported (Aghagoli et al. 2020). Meanwhile, immunohistochemical staining of autopsy materials revealed clear infiltration of monocytes and macrophages plus $T$ cells accompanied by increased expression of the cytokine and monokine induced by gamma interferon (Ellul et al. 2020).

However, molecular examination of autopsy brain materials using quantitative RT-PCR (qRT-PCR) identified SARS-CoV-2 RNA in microvascular endothelial cells of the frontal lobe (Alquisiras-Burgos et al. 2020).

These findings are supported by Paniz-Mondolfi and his team who reported the presence of pleomorphic spherical viral particles in frontal lobe tissue and endothelial cell samples following their examination with electron microscope. These findings confirmed previous reports describing SARS-CoV-2 transcellular penetration across the brain microvascular endothelial cells (Paniz-Mondolfi et al. 2020). Conversely, immunohistochemical and histopathological examination of brain tissues of 18 patients could not reveal any cytoplasmic viral staining on positive results. A complete absence of any specific brain changes referable to SARS-CoV-2 was noticed (Solomon et al. 2020).

\section{Long-term effects of coronavirus infection on the brain and its consequences}

Neurological complications resulting from COVID-19 infection results not only in short term nervous signs but persist in the form of long term consequences such as insomnia (in $26 \%$ ), myalgia (63\%), anxiety and depression (23\%) of the cases in addition to headache, dizziness, and seizures (Huang et al. 2021). The loss of smell and taste may partially or completely persist in some patients after the recovery of the patients (Netland et al. 2008; Meppiel et al. 2020; Scheidl et al. 2020b).

Serious neurological long term consequences were also reported including encephalopathy, encephalitis, stroke, and acute peripheral nerve diseases. Moreover, patients suffering from demyelination and axonal type of GBS, Miller-Fisher syndrome, and Kawasaki-like multisystem inflammatory syndromes in children and teenagers were also reported. These serious neurological damages develop as consequences of brain damage due to direct viral infection (encephalitis), due to intravascular coagulation and endothelial dysfunction / cerebrovascular ischemia (strokes), or as a result of severe immunological response and cytokine storm leading to autoimmune events (e.g., acute demyelinating inflammatory polyneuropathy/GBS, Parkinson's disease, multiple sclerosis and narcolepsy) (Scheidl et al. 2020a; Heneka et al. 2020; Varatharaj et al. 2020).
On the contrary, other reports suggest that the neurodegenerative disorder such as Parkinson's disease in COVID-19 patients may result from direct viral invasion to the brain via the olfactory tracts and spread towards the brain rather than being a consequence of severe immune response. This hypothesis is supported by neuropathological evidence showing that the Lewy bodies accumulate and are localized first in the olfactory pathway before extending to other parts of the brain. (Schirinzi et al. 2020)

it is worthy to mention that neuropsychiatric aspects of COVID-19, even in healthy individuals, must be taken into consideration. Such disorders can occur due to prolonged stressful situations (e.g., the fear of infection, social distancing, and economic pressure) that may induce post-traumatic stress disorder and other neuropsychiatric syndromes (Bossù et al. 2020).

\section{Conclusion}

COVID-19 is a highly contagious disease which infected almost 100 million persons worldwide within its first year. The high contagiousness of the diseases beside its high fatality rates makes it one of the worst epidemics in the last decades. The involvement of the nervous system, among other body systems, during the course of the disease and its major role in the elevation of mortality rate is now well documented. The virus can reach the central nervous system via various routes, inducing BBB dysfunction and initiating different degenerative neurological changes through direct and indirect mechanisms. Therefore, even recovered patients may continue to suffer from persisting neurological and psychological disorders. It is very important to deeply examine CSF and P.M. brain samples to clear the exact role of the involvement of the nervous system and possible disease pathogenesis. The collected data will aid in the development of better diagnostic tools and therapeutic approaches, which will increase the survival rate of the patients and improve the life quality of the recovered persons.

Availability of data and materials Not applicable.

Author contribution $\mathrm{AE}$ and $\mathrm{MK}$ wrote the initial draft of the manuscript. LA, AE, and MK significantly reviewed and critically revised the paper. All authors have contributed to the paper, read, edited, and finally approved the final manuscript.

\section{Declarations}

Conflict of interest The authors declare no conflict of interest. 


\section{References}

Aghagoli G, Gallo Marin B, Katchur NJ, Chaves-Sell F, Asaad WF, Murphy SA (2020) Neurological involvement in COVID-19 and potential mechanisms: a review. Neurocritical Care. https://doi.org/ 10.1007/s12028-020-01049-4

Alluwaimi AM, Alshubaith IH, Al-Ali AM, Abohelaika S (2020) The coronaviruses of animals and birds: their zoonosis, vaccines, and models for SARS-CoV and SARS-CoV2. Front Vet Sci 7:582287. https://doi.org/10.3389/fvets.2020.582287

Alquisiras-Burgos I, Peralta-Arrieta I, Alonso-Palomares LA, ZacapalaGómez AE, Salmerón-Bárcenas EG, Aguilera P (2020) Neurological complications associated with the blood-brain barrier damage induced by the inflammatory response during SARS-CoV-2 infection. Mol Neurobiol:1-16. doi: https://doi.org/10.1007/ s12035-020-02134-7

Anoop UR, Verma K (2020) Pulmonary edema in COVID19 - a neural hypothesis. ACS chemical neuroscience 11(14):2048-2050. https:// doi.org/10.1021/acschemneuro.0c00370

Bachmann MF, Mohsen MO, Zha L, Vogel M, Speiser DE (2021) SARS-CoV-2 structural features may explain limited neutralizingantibody responses. NPJ Vaccines 6(1):2. https://doi.org/10.1038/ s41541-020-00264-6

Baig AM, Sanders EC (2020) Potential neuroinvasive pathways of SARS-CoV-2: deciphering the spectrum of neurological deficit seen in coronavirus disease-2019 (COVID-19). J Med Virol. 92:18451857. https://doi.org/10.1002/jmv.26105

Becerra-Flores M, Cardozo T (2020) SARS-CoV-2 viral spike G614 mutation exhibits higher case fatality rate. Int $\mathrm{J}$ Clin Pract 74 : e13525-e13525. https://doi.org/10.1111/ijcp.13525

Bernard-Valnet R, Pizzarotti B, Anichini A, Demars Y, Russo E, Schmidhauser M, Cerruti-Sola J, Rossetti AO, Du Pasquier R (2020) Two patients with acute meningo-encephalitis concomitant to SARS-CoV-2 infection. https://doi.org/10.1101/2020.04.17. 20060251

Bittmann S, Luchter E, Villalon G, Moschüring-Alieva E, Weissenstein A (2020) Clinical landmarks of COVID-19 in newborn, children and teenagers. Journal of Pediatric Health and Nutrition 1(3):1-2. https://doi.org/10.14302/issn.2691-5014.jphn-20-3295

Bossù P, Toppi E, Sterbini V, Spalletta G (2020) Implication of aging related chronic neuroinflammation on COVID-19 pandemic. J Pers Med 10(3):102. https://doi.org/10.3390/jpm10030102

Buzhdygan TP, DeOre BJ, Baldwin-Leclair A, Bullock TA, McGary HM, Khan JA, Razmpour R, Hale JF, Galie PA, Potula R, Andrews AM, Ramirez SH (2020) The SARS-CoV-2 spike protein alters barrier function in 2D static and 3D microfluidic in-vitro models of the human blood-brain barrier. Neurobiol Dis 146: 105131. https://doi.org/10.1016/j.nbd.2020.105131

Carrillo-Larco RM, Altez-Fernandez C (2020) Anosmia and dysgeusia in COVID-19: a systematic review. Wellcome Open Research 5:94. https://doi.org/10.12688/wellcomeopenres.15917.1

Gemma Chavarria-Miró, Eduard Anfruns-Estrada, Susana Guix, Miquel Paraira, Belén Galofré, Gloria Sáanchez, Rosa Pintó, Albert Bosch (2020) Sentinel surveillance of SARS-CoV-2 in wastewater anticipates the occurrence of COVID-19 cases. doi: https://doi.org/10. 1101/2020.06.13.20129627

Chen M, Shen W, Rowan NR, Kulaga H, Hillel A, Ramanathan M, Lane AP (2020a) Elevated ACE2 expression in the olfactory neuroepithelium: implications for anosmia and upper respiratory SARS-CoV-2 entry and replication. European Respiratory Journal. https://doi.org/10.1183/13993003.01948-2020

Chen T, Wu D, Chen H, Yan W, Yang D, Chen G, Ma K, Xu D, Yu H, Wang H, Wang T (2020b) Clinical characteristics of 113 deceased patients with coronavirus disease 2019: retrospective study. BMJ. https://doi.org/10.1136/bmj.m1295
Chhetri S, Khamis F, Pandak N, Al Khalili H, Said E, Petersen E (2020) A fatal case of COVID-19 due to metabolic acidosis following dysregulate inflammatory response (cytokine storm). IDCases 21: e00829-e00829. https://doi.org/10.1016/j.idcr.2020.e00829

Chigr F, Merzouki M, Najimi M (2020) Autonomic brain centers and pathophysiology of COVID-19. ACS Chemical Neuroscience 11(11):1520-1522. https://doi.org/10.1021/acschemneuro.0c00265

Clausen TM, Sandoval DR, Spliid CB, Pihl J, Painter CD, Thacker BE, Glass CA, Narayanan A, Majowicz SA, Zhang Y, Torres JL, Golden GJ, Porell R, Garretson AF, Laubach L, Feldman J, Yin $\mathrm{X}, \mathrm{Pu}$ Y, Hauser B, Caradonna TM, Kellman BP, Martino C, Gordts PLSM, Leibel SL, Chanda SK, Schmidt AG, Godula K, Jose J, Corbett KD, Ward AB, Carlin AF, Esko JD (2020) SARSCoV-2 Infection depends on cellular heparan sulfate and ACE2. https://doi.org/10.1101/2020.07.14.201616

Colavita F, Lapa D, Carletti F, Lalle E, Bordi L, Marsella P, Nicastri E, Bevilacqua N, Giancola ML, Corpolongo A, Ippolito G, Capobianchi MR, Castilletti C (2020) SARS-CoV-2 isolation from ocular secretions of a patient with COVID-19 in Italy with prolonged viral RNA detection. Annals of Internal Medicine 173(3):242-243. https://doi.org/10.7326/m20-1176

Coolen T, Lolli V, Sadeghi N, Rovaï A, Trotta N, Taccone FS, Creteur J, Henrard S, Goffard J-C, de Witte O, Naeije G, Goldman S, de Tiège X (2020) Early postmortem brain MRI findings in COVID-19 nonsurvivors. Neurology. https://doi.org/10.1212/WNL. 0000000000010116

Costa S, Posteraro B, Marchetti S, Tamburrini E, Carducci B, Lanzone A, Valentini P, Buonsenso D, Sanguinetti M, Vento G, Cattani P (2020) Excretion of SARS-CoV-2 in human breast milk. Clinical Microbiology and Infection. 26:1430-1432. https://doi.org/10. 1016/j.cmi.2020.05.027

Cui J, Li F, Shi Z-L (2019) Origin and evolution of pathogenic coronaviruses. Nat Rev Microbiol 17(3):181-192. https://doi.org/ 10.1038/s41579-018-0118-9

Das G, Mukherjee N, Ghosh S (2020) Neurological insights of COVID19 pandemic. ACS chemical neuroscience 11(9):1206-1209. https://doi.org/10.1021/acschemneuro.0c00201

Desforges M, Le Coupanec A, Dubeau P, Bourgouin A, Lajoie L, Dubé M, Talbot PJ (2019) Human coronaviruses and other respiratory viruses: underestimated opportunistic pathogens of the central nervous system? Viruses 12(1). https://doi.org/10.3390/v12010014

Deslandes A, Berti V, Tandjaoui-Lambotte Y, Alloui C, Carbonnelle E, Zahar JR, Brichler S, Cohen Y (2020) SARS-CoV-2 was already spreading in France in late December 2019. International Journal of Antimicrobial Agents 55(6):106006. https://doi.org/10.1016/j. ijantimicag.2020.106006

Dixon L, Varley J, Gontsarova A, Mallon D, Tona F, Muir D, Luqmani A, Jenkins IH, Nicholas R, Jones B, Everitt A (2020) COVID-19related acute necrotizing encephalopathy with brain stem involvement in a patient with aplastic anemia. Neurol Neuroimmunol Neuroinflamm 7(5):e789. https://doi.org/10.1212/NXI. 0000000000000789

Dong N, Yang X, Ye L, Chen K, Chan EW-C, Yang M, Chen S (2020) Genomic and protein structure modelling analysis depicts the origin and infectivity of 2019-nCoV, a new coronavirus which caused a pneumonia outbreak in Wuhan, China. https://doi.org/10.1101/ 2020.01.20.913368

Edwards SP, Kasten S, Nelson C, Elner V, McKean E (2020) Maxillofacial trauma management during COVID-19: multidisciplinary recommendations. Facial Plastic Surgery \& Aesthetic Medicine 22(3):157-159. https://doi.org/10.1089/fpsam.2020.0158

Eliezer M, Hautefort C, Hamel A-L, Verillaud B, Herman P, Houdart E, Eloit C (2020) Sudden and complete olfactory loss of function as a possible symptom of COVID-19. JAMA Otolaryngol Head Neck Surg 146(7):674-675. https://doi.org/10.1001/jamaoto.2020.0832 
Ellul MA, Benjamin L, Singh B, Lant S, Michael BD, Easton A, Kneen R, Defres S, Sejvar J, Solomon T (2020) Neurological associations of COVID-19. Lancet Neurol 19(9):767-783. https://doi.org/10. 1016/S1474-4422(20)30221-0

Fears AC, Klimstra WB, Duprex P, Hartman A, Weaver SC, Plante KS, Mirchandani D, Plante JA, Aguilar PV, Fernández D, Nalca A, Totura A, Dyer D, Kearney B, Lackemeyer M, Bohannon JK, Johnson R, Garry RF, Reed DS, Roy CJ (2020) Persistence of severe acute respiratory syndrome coronavirus 2 in aerosol suspensions. Emerging Infectious Diseases 26(9):2168-2171. https://doi. org/10.3201/eid2609.201806

Fehr AR, Perlman S (2015) Coronaviruses: an overview of their replication and pathogenesis. Methods Mol Biol 1282:1-23. https://doi. org/10.1007/978-1-4939-2438-7_1

Fiedler E, Gill R (2020) Teaching NeuroImages: Ondine curse syndrome caused by dorsolateral medullary stroke. Neurology 94(14):e1557e1558. https://doi.org/10.1212/wnl.0000000000009219

Gao Y-M, Xu G, Wang B, Liu B-C (2020) Cytokine storm syndrome in coronavirus disease 2019: A narrative review. J Intern Med. https:// doi.org/10.1111/joim. 13144

Garg R (2020) Spectrum of neurological manifestations in Covid-19: a review. Neurology India 68(3):560. https://doi.org/10.4103/00283886.289000

Garg RK, Paliwal VK, Gupta A (2020) Encephalopathy in patients with COVID-19: A review. J Med Virol. 93:206-222. https://doi.org/10. $1002 / j m v .26207$

Gheblawi M, Wang K, Viveiros A, Nguyen Q, Zhong J-C, Turner AJ, Raizada MK, Grant MB, Oudit GY (2020) Angiotensin-converting enzyme 2: SARS-CoV-2 receptor and regulator of the reninangiotensin system: celebrating the 20th anniversary of the discovery of ACE2. Circ Res 126(10):1456-1474. https://doi.org/10.1161/ CIRCRESAHA.120.317015

Goad J, Rudolph J, Rajkovic A (2020) Female reproductive tract has low concentration of SARS-CoV2 receptors. bioRxiv. https://doi.org/10. 1101/2020.06.20.163097

Gutiérrez-Ortiz C, Méndez A, Rodrigo-Rey S, San Pedro-Murillo E, Bermejo-Guerrero L, Gordo-Mañas R, de Aragón-Gómez F, Benito-León J (2020) Miller Fisher Syndrome and polyneuritis cranialis in COVID-19. Neurology. https://doi.org/10.1212/wnl. 0000000000009619

Harbourt D, Haddow A, Piper A, Bloomfield H, Kearney B, Gibson K, Minogue T (2020) Modeling the stability of severe acute respiratory syndrome coronavirus 2 (SARS-CoV-2) on skin, currency, and clothing. https://doi.org/10.1101/2020.07.01.20144253

Heneka MT, Golenbock D, Latz E, Morgan D, Brown R (2020) Immediate and long-term consequences of COVID-19 infections for the development of neurological disease. Alzheimers Res Ther 12(1):69. https://doi.org/10.1186/s13195-020-00640-3

Hie B, Zhong ED, Berger B, Bryson B (2021) Learning the language of viral evolution and escape. Science 371(6526):284-288. https://doi. org/10.1126/science.abd7331

Hjelmesæth J, Skaare D (2020) Covid-19 med nedsatt lukte- og smakssans som eneste symptom. Tidsskrift for Den norske legeforening. https://doi.org/10.4045/tidsskr.20.0287

Holtmann N, Edimiris P, Andree M, Doehmen C, Baston-Buest D, Adams O, Kruessel J-S, Bielfeld AP (2020) Assessment of SARSCoV-2 in human semenltextemdasha cohort study. Fertility and Sterility 114(2):233-238. https://doi.org/10.1016/j.fertnstert.2020. 05.028

Huang J, Zheng M, Tang X, Chen Y, Tong A, Zhou L (2020) Potential of SARS-CoV-2 to Cause CNS Infection: biologic fundamental and clinical experience. Front Neurol 11. https://doi.org/10.3389/fneur. 2020.00659

Huang C, Huang L, Wang Y, Li X, Ren L, Gu X, Kang L, Guo L, Liu M, Zhou X, Luo J, Huang Z, Tu S, Zhao Y, Chen L, Xu D, Li Y, Li C, Peng L, Li Y, Xie W, Cui D, Shang L, Fan G, Xu J, Wang G, Wang
Y, Zhong J, Wang C, Wang J, Zhang D, Cao B (2021) 6-month consequences of COVID-19 in patients discharged from hospital: a cohort study. The Lancet 397(10270):220-232. https://doi.org/10. 1016/S0140-6736(20)32656-8

Hussain A, Hasan A, Nejadi Babadaei MM, Bloukh SH, Chowdhury MEH, Sharifi M, Haghighat S, Falahati M (2020) Targeting SARS-CoV2 spike protein receptor binding domain by therapeutic antibodies. Biomed Pharmacother 130:110559. https://doi.org/10. 1016/j.biopha.2020.110559

Jaimes JA, Millet JK, Whittaker GR (2020) Proteolytic cleavage of the SARS-CoV-2 spike protein and the role of the novel S1/S2 site. iScience 23(6):101212. https://doi.org/10.1016/j.isci.2020.101212

Jakhmola S, Indari O, Chatterjee S, Jha HC (2020) SARS-CoV-2, an underestimated pathogen of the nervous system. SN Compr Clin Med 1-10. doi: https://doi.org/10.1007/s42399-020-00522-7

Jayaweera M, Perera H, Gunawardana B, Manatunge J (2020) Transmission of COVID-19 virus by droplets and aerosols: a critical review on the unresolved dichotomy. Environ Res 188:109819. https://doi.org/10.1016/j.envres.2020.109819

Jeffers SA, Tusell SM, Gillim-Ross L, Hemmila EM, Achenbach JE, Babcock GJ, Thomas WD Jr, Thackray LB, Young MD, Mason RJ, Ambrosino DM, Wentworth DE, Demartini JC, Holmes KV (2004) CD209L (L-SIGN) is a receptor for severe acute respiratory syndrome coronavirus. Proc Natl Acad Sci U S A 101(44):1574815753. https://doi.org/10.1073/pnas.0403812101

Jha NK, Ojha S, Jha SK, Dureja H, Singh SK, Shukla SD, Chellappan DK, Gupta G, Bhardwaj S, Kumar N, Jeyaraman M, Jain R, Muthu S, Kar R, Kumar D, Goswami VK, Ruokolainen J, Kesari KK, Singh SK, Dua K (2021) Evidence of coronavirus (CoV) pathogenesis and emerging pathogen SARS-CoV-2 in the nervous system: a review on neurological impairments and manifestations. J Mol Neurosci:1-18. doi: https://doi.org/10.1007/s12031-020-01767-6

Jiang M, Li Y, Han M, Wang Z, Zhang Y, Du X (2020) Recurrent PCR positivity after hospital discharge of people with coronavirus disease 2019 (COVID-19). J Infect 81(1):147-178. https://doi.org/10.1016/ j.jinf.2020.03.024

John AL, Michael L, Z. Hugh Fan, Antarpreet SJ, Trevor BT, Mayank Gangwar, Moiz Usmani, Sripriya N Shankar, Karim Mohamed, Arantza Eiguren-Fernandez, Caroline J Stephenson, Md. Mahbubul Alam, Maha A Elbadry, Julia C Loeb, Kuttichantran Subramaniam, Thomas B Waltzek, Kartikeya Cherabuddi, John Glenn Morris, Chang-Yu Wu (2020) Viable SARS-CoV-2 in the air of a hospital room with COVID-19 patients. doi: https://doi.org/ 10.1101/2020.08.03.20167395

Kamel M, Pavulraj S, Fauler B, Mielke T, Azab W (2020) Equid herpesvirus-1 exploits the extracellular matrix of mononuclear cells to ensure transport to target cells. iScience 23((10):101615. https:// doi.org/10.1016/j.isci.2020.101615

Kantonen J, Mahzabin S, Mäyränpää MI, Tynninen O, Paetau A, Andersson N, Sajantila A, Vapalahti O, Carpén O, Kekäläinen E, Kantele A, Myllykangas L (2020) Neuropathologic features of four autopsied COVID-19 patients. Brain Pathol 30(6):1012-1016. https://doi.org/10.1111/bpa.12889

Koralnik IJ, Tyler KL (2020a) COVID-19: a global threat to the nervous system. Ann Neurol 88(1):1-11. https://doi.org/10.1002/ana.25807

Koralnik IJ, Tyler KL (2020b) COVID-19: a global threat to the nervous system. Ann Neurol 88(1):1-11. https://doi.org/10.1002/ana.25807

Lechien JR, Hopkins C, Saussez S (2020) Letter to the Editor about the Beltrán-Corbellini et al. publication: 'acute-onset smell and taste disorders in the context of Covid-19: a pilot multicenter PCRbased case-control study. Eur J Neurol. https://doi.org/10.1111/ ene. 14357

Leyi W (2016) Animal Coronaviruses. https://doi.org/10.1007/978-14939-3414-0

Li W, Moore MJ, Vasilieva N, Sui J, Wong SK, Berne MA, Somasundaran M, Sullivan JL, Luzuriaga K, Greenough TC, Choe 
H, Farzan M (2003) Angiotensin-converting enzyme 2 is a functional receptor for the SARS coronavirus. Nature 426(6965):450-454. https://doi.org/10.1038/nature02145

Li W, Sui J, Huang I-C, Kuhn JH, Radoshitzky SR, Marasco WA, Choe H, Farzan M (2007) The S proteins of human coronavirus NL63 and severe acute respiratory syndrome coronavirus bind overlapping regions of ACE2. Virology 367(2):367-374. https://doi.org/10.1016/j. virol.2007.04.035

Li G, Fan Y, Lai Y, Han T, Li Z, Zhou P, Pan P, Wang W, Hu D, Liu X, Zhang Q, Wu J (2020a) Coronavirus infections and immune responses. J Med Virol 92(4):424-432. https://doi.org/10.1002/jmv. 25685

Li H, Xue Q, Xu X (2020b) Involvement of the nervous system in SARSCoV-2 infection. Neurotox Res 38(1):1-7. https://doi.org/10.1007/ s12640-020-00219-8

Li M-Y, Li L, Zhang Y, Wang X-S (2020c) Expression of the SARS$\mathrm{CoV}-2$ cell receptor gene ACE2 in a wide variety of human tissues. Infect Dis Poverty 9(1):45. https://doi.org/10.1186/s40249-02000662-X

Li Y-C, Bai W-Z, Hashikawa T (2020d) The neuroinvasive potential of SARS-CoV2 may play a role in the respiratory failure of COVID-19 patients. J Med Virol 92(6):552-555. https://doi.org/10.1002/jmv. 25728

Lima M, Siokas V, Aloizou A-M, Liampas I, Mentis A-FA, Tsouris Z, Papadimitriou A, Mitsias PD, Tsatsakis A, Bogdanos DP, Baloyannis SJ, Dardiotis E (2020) Unraveling the possible routes of SARS-COV-2 invasion into the central nervous system. Curr Treat Options Neurol 22(11):37. https://doi.org/10.1007/s11940020-00647-Z

Ling Y, Xu S-B, Lin Y-X, Tian D, Zhu Z-Q, Dai F-H, Wu F, Song Z-G, Huang W, Chen J, Hu B-J, Wang S, Mao E-Q, Zhu L, Zhang W-H, Lu H-Z (2020) Persistence and clearance of viral RNA in 2019 novel coronavirus disease rehabilitation patients. Chin Med J (Engl) 133(9):1039-1043. https://doi.org/10.1097/CM9. 0000000000000774

Long Q-X, Tang X-J, Shi Q-L, Li Q, Deng H-J, Yuan J, Hu J-L, Xu W, Zhang Y, Lv F-J, Su K, Zhang F, Gong J, Wu B, Liu X-M, Li J-J, Qiu J-F, Chen J, Huang A-L (2020) Clinical and immunological assessment of asymptomatic SARS-CoV-2 infections. Nature Medicine. 26:1200-1204. https://doi.org/10.1038/s41591-0200965-6

Lucas C, Patrick Wong, Jon Klein, Tiago Castro, Julio Silva, Maria Sundaram, Mallory Ellingson, Tianyang Mao, Jieun Oh, Benjamin Israelow, Maria Tokuyama, Peiwen Lu, Arvind Venkataraman, Annsea Park, Subhasis Mohanty, Haowei Wang, Anne Louise Wyllie, Chantal B.F. Vogels, Rebecca Earnest, Sarah Lapidus, Isabel Ott, Adam Moore, Catherine Muenker, John Fournier, Melissa Campbell, Camila Odio, Arnau Casanovas-Massana, Roy Herbst, Albert Shaw, Ruslan Medzhitov, Wade L Schulz, Nathan Grubaugh, Charles Dela Cruz, Shelli Farhadian, Albert Ko, Saad Omer, Akiko Iwasaki (2020) Longitudinal immunological analyses reveal inflammatory misfiring in severe COVID-19 patients. doi: https://doi.org/10.1101/2020.06.23.20138289

Maaroufi H (2021) Interactions of SARS-CoV-2 spike protein and transient receptor potential (TRP) cation channels could explain smell, taste, and/or chemesthesis disorders

Mahase E (2021) Covid-19: What new variants are emerging and how are they being investigated? BMJ:n158. https://doi.org/10.1136/bmj. n158

Mahmudpour M, Roozbeh J, Keshavarz M, Farrokhi S, Nabipour I (2020) COVID-19 cytokine storm: the anger of inflammation. Cytokine 133:155151. https://doi.org/10.1016/j.cyto.2020.155151

Mao L, Jin H, Wang M, Hu Y, Chen S, He Q, Chang J, Hong C, Zhou Y, Wang D, Miao X, Li Y, Hu B (2020a) Neurologic manifestations of hospitalized patients with coronavirus disease 2019 in Wuhan,
China. JAMA Neurol 77(6):1-9. https://doi.org/10.1001/ jamaneurol.2020.1127

Mao L, Wang M, Chen S, He Q, Chang J, Hong C, Zhou Y, Wang D, Li Y, Jin H, Hu B (2020b) Neurological manifestations of hospitalized patients with COVID-19 in Wuhan. China: a retrospective case series study. https://doi.org/10.1101/2020.02.22.20026500

McArthur JC (2020) The path forward: academic neurology responds to COVID-19. Ann Neurol 87(6):789-793. https://doi.org/10.1002/ ana. 25773

Mehta P, McAuley DF, Brown M, Sanchez E, Tattersall RS, Manson JJ, HLH Across Speciality Collaboration, UK (2020) COVID-19: consider cytokine storm syndromes and immunosuppression. Lancet 395(10229):1033-1034. https://doi.org/10.1016/S0140-6736(20) 30628-0

Meppiel E, Peiffer-Smadja N, Maury A, Bekri I, Delorme C, Desestret V, Gorza L, Hautecloque-Raysz G, Landre S, Lannuzel A, Moulin S, Perrin P, Petitgas P, Sellal F, Wang A, Tattevin P, de Broucker T (2020) Neurological manifestations associated with COVID-19: a nationwide registry. https://doi.org/10.1101/2020.07.15.20154260

Moriguchi T, Harii N, Goto J, Harada D, Sugawara H, Takamino J, Ueno M, Sakata H, Kondo K, Myose N, Nakao A, Takeda M, Haro H, Inoue O, Suzuki-Inoue K, Kubokawa K, Ogihara S, Sasaki T, Kinouchi H, Kojin H, Ito M, Onishi H, Shimizu T, Sasaki Y, Enomoto N, Ishihara H, Furuya S, Yamamoto T, Shimada $S$ (2020) A first case of meningitis/encephalitis associated with SARS-Coronavirus-2. Int J Infect Dis 94:55-58. https://doi.org/10. 1016/j.ijid.2020.03.062

Narain S, Stefanov DG, Chau AS, Weber AG, Marder G, Kaplan B Malhotra P, Bloom O, Liu A, Lesser ML, Hajizadeh N, Northwell COVID-19 Research Consortium (2020) Comparative survival analysis of immunomodulatory therapy for coronavirus disease 2019 cytokine storm. Chest. https://doi.org/10.1016/j.chest.2020. 09.275

Netland J, Meyerholz DK, Moore S, Cassell M, Perlman S (2008) Severe acute respiratory syndrome coronavirus infection causes neuronal death in the absence of encephalitis in mice transgenic for human ACE2. J Virol 82(15):7264-7275. https://doi.org/10.1128/JVI. 00737-08

Oxley TJ, Mocco J, Majidi S, Kellner CP, Shoirah H, Singh IP, de Leacy RA, Shigematsu T, Ladner TR, Yaeger KA, Skliut M, Weinberger J, Dangayach NS, Bederson JB, Tuhrim S, Fifi JT (2020) Large-vessel stroke as a presenting feature of covid-19 in the young. N Engl J Med 382(20):e60. https://doi.org/10.1056/NEJMc2009787

Paniz-Mondolfi A, Bryce C, Grimes Z, Gordon RE, Reidy J, Lednicky J, Sordillo EM, Fowkes M (2020) Central nervous system involvement by severe acute respiratory syndrome coronavirus-2 (SARSCoV-2). J Med Virol 92(7):699-702. https://doi.org/10.1002/jmv. 25915

Papageorgiou AC, Mohsin I (2020a) The SARS-CoV-2 spike glycoprotein as a drug and vaccine target: structural insights into its complexes with ACE2 and antibodies. Cells 9(11):2343. https://doi.org/ $10.3390 /$ cells 9112343

Papageorgiou AC, Mohsin I (2020b) The SARS-CoV-2 spike glycoprotein as a drug and vaccine target: structural insights into its complexes with ACE2 and Antibodies. Cells 9(11):2343. https://doi.org/ $10.3390 /$ cells 9112343

Park MD (2020) Macrophages: a Trojan horse in COVID-19? Nat Rev Immunol 20(6):351. https://doi.org/10.1038/s41577-020-0317-2

Passali GC, Bentivoglio AR (2020) Comment to the article "Olfactory and gustatory dysfunctions as a clinical presentation of mild-tomoderate forms of the coronavirus disease (COVID-19): a multicenter European study". Eur Arch Otorhinolaryngol 277(8):2391-2392. https://doi.org/10.1007/s00405-020-06024-5

Paterson RW, Brown RL, Benjamin L, Nortley R, Wiethoff S, Bharucha T, Jayaseelan DL, Kumar G, Raftopoulos RE, Zambreanu L, Vivekanandam V, Khoo A, Geraldes R, Chinthapalli K, Boyd E, 
Tuzlali H, Price G, Christofi G, Morrow J, McNamara P, McLoughlin B, Lim ST, Mehta PR, Levee V, Keddie S, Yong W, Trip SA, Foulkes AJM, Hotton G, Miller TD, Everitt AD, Carswell C, Davies NWS, Yoong M, Attwell D, Sreedharan J, Silber E, Schott JM, Chandratheva A, Perry RJ, Simister R, Checkley A, Longley N, Farmer SF, Carletti F, Houlihan C, Thom M, Lunn MP, Spillane J, Howard R, Vincent A, Werring DJ, Hoskote C, Jäger HR, Manji H, Zandi MS (2020a) The emerging spectrum of COVID-19 neurology: clinical, radiological and laboratory findings. Brain. 143:3104-3120. https://doi.org/10.1093/brain/awaa240

Paterson RW, Brown RL, Benjamin L, Nortley R, Wiethoff S, Bharucha T, Jayaseelan DL, Kumar G, Raftopoulos RE, Zambreanu L, Vivekanandam V, Khoo A, Geraldes R, Chinthapalli K, Boyd E, Tuzlali H, Price G, Christofi G, Morrow J, McNamara P, McLoughlin B, Lim ST, Mehta PR, Levee V, Keddie S, Yong W, Trip SA, Foulkes AJM, Hotton G, Miller TD, Everitt AD, Carswell C, Davies NWS, Yoong M, Attwell D, Sreedharan J, Silber E, Schott JM, Chandratheva A, Perry RJ, Simister R, Checkley A, Longley N, Farmer SF, Carletti F, Houlihan C, Thom M, Lunn MP, Spillane J, Howard R, Vincent A, Werring DJ, Hoskote C, Jäger HR, Manji H, Zandi MS (2020b) The emerging spectrum of COVID-19 neurology: clinical, radiological and laboratory findings. Brain. 143:3104-3120. https://doi.org/10.1093/brain/awaa240

Pinzon RT, Wijaya VO, Buana RB, Al Jody A, Nunsio PN (2020a) Neurologic characteristics in coronavirus disease 2019 (COVID19): a systematic review and meta-analysis. Front Neurol 11:565. https://doi.org/10.3389/fneur.2020.00565

Pinzon RT, Wijaya VO, Buana RB, Al Jody A, Nunsio PN (2020b) Neurologic characteristics in coronavirus disease 2019 (COVID19): a systematic review and meta-analysis. Front Neurol 11:565. https://doi.org/10.3389/fneur.2020.00565

Pleasure SJ, Green AJ, Josephson SA (2020) The spectrum of neurologic disease in the severe acute respiratory syndrome coronavirus 2 pandemic infection. JAMA Neurol 77(6):679-680. https://doi.org/10. 1001/jamaneurol.2020.1065

Pollán M, Pérez-Gómez B, Pastor-Barriuso R, Oteo J, Hernán MA, Pérez-Olmeda M, Sanmartín JL, Fernández-García A, Cruz I, de Larrea NF, Molina M, Rodríguez-Cabrera F, Martín M, MerinoAmador P, Paniagua JL, Muñoz-Montalvo JF, Blanco F, Yotti R, Fernández RG, Navarro SM, Muñoz-Montalvo JF, Hernández MS, Sanmartín JL, Cuenca-Estrella M, Paniagua JL, Fernández-Navarro P, Avellón A, Fedele G, Iglesias JO, Olmeda MTP, Martinez MEF, Rodríguez-Cabrera FD, Hernán MA, Fernández SP, Aguirre JMR, Navarro Marí JM, Borrás BP, Jiménez ABP, Rodríguez-Iglesias M, Gascón AMC, Alcaine MLL, Suárez ID, Álvarez OS, Pérez MR, Sanchís MC, Gomila CJV, Saladrigas LC, Fernández AH, Oliver A, Feliciano EC, Quintana MNG, Fernández JMB, Betancor MAH, Febles MH, Martín LM, López L-ML, Miota TU, Población IDB, Pérez MSC, Fernández MNV, Enríquez TM, Arranz MV, González MD-G, Fernández-Natal I, Lobón GM, Bellido JLM, Ciruela P, Casals AM i, Botías MD, Maeso MAM, del Campo DP, de Castro AF, Ramírez RL, Retamosa MFE, González MR, Lobeiras MSB, Losada AF, Aguilera A, Bou G, Caro Y, Marauri N, Blanco LMS, del Cura González I, Pascual MH, Fernández RA, Castro NC, Lizcano AT, Almagro CR, Hernández MS, Elizaga NA, Sanz ME, Baquedano CE, Bascaran AB, Tamayo SI, Otazua LE, Benarroch RB, Flores JL, de la Villa AV (2020) Prevalence of SARS-CoV-2 in Spain (ENE-COVID): a nationwide, population-based seroepidemiological study. The Lancet 396:535-544. https://doi. org/10.1016/S0140-6736(20)31483-5

Pollan M, Perez-Gomez B, Pastor-Barriuso R, Oteo J, Hernán MA, Pérez-Olmeda M, Sanmartín JL, Fernández-García A, Cruz I, Fernández de Larrea N, Molina M, Rodríguez-Cabrera F, Martín M, Merino-Amador P, Paniagua JL, Muñoz-Montalvo JF, Blanco F, Yotti R, Study Group E-C (2020) A population-based seroepidemiological study of SARS-CoV-2 in Spain (ENE-
COVID). SSRN Electronic Journal. https://doi.org/10.2139/ssrn. 3616010

Pooladanda V, Thatikonda S, Godugu C (2020) The current understanding and potential therapeutic options to combat COVID-19. Life Sci 254:117765. https://doi.org/10.1016/j.lfs.2020.117765

Poyiadji N, Shahin G, Noujaim D, Stone M, Patel S, Griffith B (2020) COVID-19-associated acute hemorrhagic necrotizing encephalopathy: imaging features. Radiology 296(2):E119-E120. https://doi. org/10.1148/radiol.2020201187

Rhea EM, Logsdon AF, Hansen KM, Williams LM, Reed MJ, Baumann KK, Holden SJ, Raber J, Banks WA, Erickson MA (2020) The S1 protein of SARS-CoV-2 crosses the blood-brain barrier in mice. Nature Neuroscience. https://doi.org/10.1038/s41593-020-00771-8

Rodriguez-Morales AJ, Cardona-Ospina JA, Gutiérrez-Ocampo E, Villamizar-Peña R, Holguin-Rivera Y, Escalera-Antezana JP, Alvarado-Arnez LE, Bonilla-Aldana DK, Franco-Paredes C, Henao-Martinez AF, Paniz-Mondolfi A, Lagos-Grisales GJ, Ramírez-Vallejo E, Suárez JA, Zambrano LI, Villamil-Gómez WE, Balbin-Ramon GJ, Rabaan AA, Harapan H, Dhama K, Nishiura H, Kataoka H, Ahmad T, Sah R, Latin American Network of Coronavirus Disease 2019-COVID-19 Research (LANCOVID-19). Electronic address: https://www.lancovid.org (2020) Clinical, laboratory and imaging features of COVID-19: a systematic review and meta-analysis. Travel Med Infect Dis 34: 101623. https://doi.org/10.1016/j.tmaid.2020.101623

Rogers JP, Chesney E, Oliver D, Pollak TA, McGuire P, Fusar-Poli P, Zandi MS, Lewis G, David AS (2020) Psychiatric and neuropsychiatric presentations associated with severe coronavirus infections: a systematic review and meta-analysis with comparison to the COVID-19 pandemic. Lancet Psychiatry 7(7):611-627. https://doi. org/10.1016/S2215-0366(20)30203-0

Román GC, Spencer PS, Reis J, Buguet A, MEA F, Katrak SM, Láinez M, Medina MT, Meshram C, Mizusawa H, Öztürk S, Wasay M, WFN Environmental Neurology Specialty Group (2020) The neurology of COVID-19 revisited: a proposal from the Environmental Neurology Specialty Group of the World Federation of Neurology to implement international neurological registries. J Neurol Sci 414: 116884. https://doi.org/10.1016/j.jns.2020.116884

Saif LJ (2004) Animal coronaviruses : what can they teach us about the severe acute respiratory syndrome? Rev. Sci. Tech. OIE 23(2):643660. https://doi.org/10.20506/rst.23.2.1513

Satarker S, Nampoothiri M (2020) Involvement of the nervous system in COVID-19: The bell should toll in the brain. Life Sci 262:118568. https://doi.org/10.1016/j.lfs.2020.118568

Scheidl E, Canseco DD, Hadji-Naumov A, Bereznai B (2020a) GuillainBarré syndrome during SARS-CoV-2 pandemic: a case report and review of recent literature. J Peripher Nerv Syst 25(2):204-207. https://doi.org/10.1111/jns.12382

Scheidl E, Canseco DD, Hadji-Naumov A, Bereznai B (2020b) GuillainBarré syndrome during SARS-CoV-2 pandemic: a case report and review of recent literature. Journal of the Peripheral Nervous System 25(2):204-207. https://doi.org/10.1111/jns.12382

Schirinzi T, Landi D, Liguori C (2020) COVID-19: dealing with a potential risk factor for chronic neurological disorders. J Neurol:1-8. https://doi.org/10.1007/s00415-020-10131-y

Schwarzkopf S, Krawczyk A, Knop D, Klump H, Heinold A, Heinemann FM, Thümmler L, Temme C, Breyer M, Witzke O, Dittmer U, Lenz V, Horn PA, Lindemann M (2021) Cellular immunity in COVID-19 convalescents with PCR-confirmed infection but with undetectable SARS-CoV-2-specific IgG. Emerging Infectious Diseases 27(1): 122-129. https://doi.org/10.3201/eid2701.203772

Scoppettuolo P, Borrelli S, Naeije G (2020) Neurological involvement in SARS-CoV-2 infection: a clinical systematic review. Brain, Behavior, \& Immunity - Health 5:100094. https://doi.org/10.1016/ j.bbih.2020.100094 
Sedaghat Z, Karimi N (2020) Guillain Barre syndrome associated with COVID-19 infection: a case report. J Clin Neurosci 76:233-235. https://doi.org/10.1016/j.jocn.2020.04.062

Sharifi-Razavi A, Karimi N, Rouhani N (2020) COVID-19 and intracerebral haemorrhage: causative or coincidental? New Microbes New Infect 35:100669. https://doi.org/10.1016/j.nmni.2020.100669

Sheraton M, Deo N, Kashyap R, Surani S (2020) A review of neurological complications of COVID-19. Cureus 12(5):e8192-e8192. https://doi.org/10.7759/cureus.8192

Solomon IH, Normandin E, Bhattacharyya S, Mukerji SS, Keller K, Ali AS, Adams G, Hornick JL, Padera RF, Sabeti P (2020) Neuropathological features of Covid-19. New England Journal of Medicine. 383:989-992. https://doi.org/10.1056/nejmc2019373

Steardo L, Steardo L Jr, Zorec R, Verkhratsky A (2020) Neuroinfection may contribute to pathophysiology and clinical manifestations of COVID-19. Acta Physiol (Oxf) 229(3):e13473-e13473. https:// doi.org/10.1111/apha.13473

Struyf T, Deeks JJ, Dinnes J, Takwoingi Y, Davenport C, Leeflang MM, Spijker R, Hooft L, Emperador D, Dittrich S, Domen J, SRA H, van den Bruel A, Cochrane COVID-19 Diagnostic Test Accuracy Group (2020) Signs and symptoms to determine if a patient presenting in primary care or hospital outpatient settings has COVID-19 disease. Cochrane Database Syst Rev 7(7):CD013665-CD013665. https:// doi.org/10.1002/14651858.CD013665

Sun J, Zhu A, Li H, Zheng K, Zhuang Z, Chen Z, Shi Y, Zhang Z, Chen S-B, Liu X, Dai J, Li X, Huang S, Huang X, Luo L, Wen L, Zhuo J, Li Y, Wang Y, Zhang L, Zhang Y, Li F, Feng L, Chen X, Zhong N, Yang Z, Huang J, Zhao J, Li Y-M (2020) Isolation of infectious SARS-CoV-2 from urine of a COVID-19 patient. Emerg Microbes Infect 9(1):991-993. https://doi.org/10.1080/22221751.2020. 1760144

Tremblay M-E, Madore C, Bordeleau M, Tian L, Verkhratsky A (2020) Neuropathobiology of COVID-19: the role for glia. Front Cell Neurosci 14:592214. https://doi.org/10.3389/fncel.2020.592214

van Doremalen N, Miazgowicz KL, Milne-Price S, Bushmaker T, Robertson S, Scott D, Kinne J, McLellan JS, Zhu J, Munster VJ (2014) Host species restriction of Middle East respiratory syndrome coronavirus through its receptor, dipeptidyl peptidase 4. J Virol 88(16):9220-9232. https://doi.org/10.1128/JVI.00676-14

Varatharaj A, Thomas N, Ellul M, Davies NWS, Pollak T, Tenorio EL, Sultan M, Easton A, Breen G, Zandi M, Coles JP, Manji H, AlShahi Salman R, Menon D, Nicholson T, Benjamin L, Carson A, Smith C, Turner MR, Solomon T, Kneen R, Pett S, Galea I, Thomas RH, Michael B (2020) UK-wide surveillance of neurological and neuropsychiatric complications of COVID-19: the first 153 patients. SSRN Electronic Journal. https://doi.org/10.2139/ssrn.3601761

Vargas G, Medeiros Geraldo LH, Gedeão Salomão N, Viana Paes M, Regina Souza Lima F, Carvalho Alcantara Gomes F (2020) Severe acute respiratory syndrome coronavirus 2 (SARS-CoV-2) and glial cells: insights and perspectives. Brain Behav Immun Health 7: 100127. https://doi.org/10.1016/j.bbih.2020.100127

Varma P, Lybrand ZR, Antopia MC, Hsieh J (2021) Novel targets of SARS-CoV-2 spike protein in human fetal brain development suggest early pregnancy vulnerability. Frontiers in Neuroscience 14. https://doi.org/10.3389/fnins.2020.614680

Vasquez-Bonilla WO, Orozco R, Argueta V, Sierra M, Zambrano LI, Muñoz-Lara F, López-Molina DS, Arteaga-Livias K, Grimes Z, Bryce C, Paniz-Mondolfi A, Rodríguez-Morales AJ (2020) A review of the main histopathological findings in the coronavirus disease 2019 (COVID-19). Human Pathology. 105:74-83. https://doi. org/10.1016/j.humpath.2020.07.023

Velavan TP, Meyer CG (2020) The COVID-19 epidemic. Trop Med Int Health 25(3):278-280. https://doi.org/10.1111/tmi.13383

Wang A, Zhou Y, Jiang N, Zhou Q, Ma W-L (2020) Persistence of intestinal SARS-CoV-2 infection in patients with COVID-19 leads to re-admission after pneumonia resolved. International Journal of
Infectious Diseases 95:433-435. https://doi.org/10.1016/j.ijid.2020. 04.063

Watanabe Y, Allen JD, Wrapp D, McLellan JS, Crispin M (2020) Sitespecific glycan analysis of the SARS-CoV-2 spike. Science 369(6501):330-333. https://doi.org/10.1126/science.abb9983

Wei H, Yin H, Huang M, Guo Z (2020) The 2019 novel cornoavirus pneumonia with onset of oculomotor nerve palsy: a case study. J Neurol 267(5):1550-1553. https://doi.org/10.1007/s00415-02009773-9

Wong ACP, Li X, Lau SKP, Woo PCY (2019) Global epidemiology of bat coronaviruses. Viruses 11(2):174. https://doi.org/10.3390/ v11020174

Woo PCY, Lau SKP, Lam CSF, Lau CCY, Tsang AKL, Lau JHN, Bai R, Teng JLL, Tsang CCC, Wang M, Zheng B-J, Chan K-H, Yuen K-Y (2012) Discovery of seven novel mammalian and avian coronaviruses in the genus deltacoronavirus supports bat coronaviruses as the gene source of alphacoronavirus and betacoronavirus and avian coronaviruses as the gene source of gammacoronavirus and deltacoronavirus. J Virol 86(7):39954008. https://doi.org/10.1128/JVI.06540-11

Wu K, Li W, Peng G, Li F (2009) Crystal structure of NL63 respiratory coronavirus receptor-binding domain complexed with its human receptor. Worldwide Protein Data Bank

Wu Y, Xu X, Chen Z, Duan J, Hashimoto K, Yang L, Liu C, Yang C (2020) Nervous system involvement after infection with COVID-19 and other coronaviruses. Brain Behav Immun 87:18-22. https://doi. org/10.1016/j.bbi.2020.03.031

Xia S, Zhu Y, Liu M, Lan Q, Xu W, Wu Y, Ying T, Liu S, Shi Z, Jiang S, $\mathrm{Lu} \mathrm{L}$ (2020) Fusion mechanism of 2019-nCoV and fusion inhibitors targeting HR1 domain in spike protein. Cell Mol Immunol 17(7): 765-767. https://doi.org/10.1038/s41423-020-0374-2

Xiao F, Sun J, Xu Y, Li F, Huang X, Li H, Zhao J, Huang J, Zhao J (2020) Infectious SARS-CoV-2 in feces of patient with severe COVID-19. Emerging Infectious Diseases 26(8):1920-1922. https://doi.org/10. 3201/eid2608.200681

Xu Z, Shi L, Wang Y, Zhang J, Huang L, Zhang C, Liu S, Zhao P, Liu H, Zhu L, Tai Y, Bai C, Gao T, Song J, Xia P, Dong J, Zhao J, Wang F$S$ (2020) Pathological findings of COVID-19 associated with acute respiratory distress syndrome. Lancet Respir Med 8(4):420-422. https://doi.org/10.1016/S2213-2600(20)30076-X

Yaghi S, Ishida K, Torres J, Mac Grory B, Raz E, Humbert K, Henninger N, Trivedi T, Lillemoe K, Alam S, Sanger M, Kim S, Scher E, Dehkharghani S, Wachs M, Tanweer O, Volpicelli F, Bosworth B, Lord A, Frontera J (2020) SARS-CoV-2 and stroke in a New York healthcare system. Stroke 51(7):2002-2011. https://doi.org/10. 1161/STROKEAHA.120.030335

Yeager CL, Ashmun RA, Williams RK, Cardellichio CB, Shapiro LH, Look AT, Holmes KV (1992) Human aminopeptidase N is a receptor for human coronavirus 229E. Nature 357(6377):420-422. https://doi.org/10.1038/357420a0

Zanin L, Saraceno G, Panciani PP, Renisi G, Signorini L, Migliorati K, Fontanella MM (2020) SARS-CoV-2 can induce brain and spine demyelinating lesions. Acta Neurochir (Wien) 162(7):1491-1494. https://doi.org/10.1007/s00701-020-04374-x

Zhang J, Tecson KM, McCullough PA (2020a) Endothelial dysfunction contributes to COVID-19-associated vascular inflammation and coagulopathy. Reviews in Cardiovascular Medicine 21(3):315. https:// doi.org/10.31083/j.rcm.2020.03.126

Zhang L, Jackson CB, Mou H, Ojha A, Rangarajan ES, Izard T, Farzan M, Choe H (2020b) The D614G mutation in the SARS-CoV-2 spike protein reduces $\mathrm{S} 1$ shedding and increases infectivity. bioRxiv. https://doi.org/10.1101/2020.06.12.148726

Zhang R, Li Y, Zhang AL, Wang Y, Molina MJ (2020c) Identifying airborne transmission as the dominant route for the spread of COVID-19. Proc Natl Acad Sci U S A 117(26):14857-14863. https://doi.org/10.1073/pnas.2009637117 
Zhang Y, Xiao M, Zhang S, Xia P, Cao W, Jiang W, Chen H, Ding X, Zhao H, Zhang H, Wang C, Zhao J, Sun X, Tian R, Wu W, Wu D, Ma J, Chen Y, Zhang D, Xie J, Yan X, Zhou X, Liu Z, Wang J, Du B, Qin Y, Gao P, Qin X, Xu Y, Zhang W, Li T, Zhang F, Zhao Y, Li Y, Zhang S (2020d) Coagulopathy and antiphospholipid antibodies in patients with Covid-19. N Engl J Med 382(17):e38-e38. https:// doi.org/10.1056/NEJMc2007575

Zhang Y, Xiao M, Zhang S, Xia P, Cao W, Jiang W, Chen H, Ding X, Zhao H, Zhang H, Wang C, Zhao J, Sun X, Tian R, Wu W, Wu D, Ma J, Chen Y, Zhang D, Xie J, Yan X, Zhou X, Liu Z, Wang J, Du B, Qin Y, Gao P, Qin X, Xu Y, Zhang W, Li T, Zhang F, Zhao Y, Li Y, Zhang S (2020e) Coagulopathy and antiphospholipid antibodies in patients with Covid-19. N Engl J Med 382(17):e38-e38. https:// doi.org/10.1056/NEJMc2007575

Zubair AS, McAlpine LS, Gardin T, Farhadian S, Kuruvilla DE, Spudich $S$ (2020) Neuropathogenesis and neurologic manifestations of the coronaviruses in the age of coronavirus disease 2019. JAMA Neurol. 77:1018-1027. https://doi.org/10.1001/jamaneurol.2020. 2065

Publisher's note Springer Nature remains neutral with regard to jurisdictional claims in published maps and institutional affiliations. 